\title{
SŁOWO WPROWADZAJĄCE W PROBLEMATYKĘ CZASOPISMA „RELACJE MIĘDZYKULTUROWE”
}

Instytut Studiów Międzykulturowych (ISM) Wydziału Studiów Międzynarodowych i Politycznych Uniwersytetu Jagiellońskiego uruchomił w 2014 roku studia pierwszego oraz drugiego stopnia na unikatowym w skali naszego kraju kierunku: relacje międzykulturowe ${ }^{1}$. Naukowcy oraz dydaktycy zatrudnieni w Instytucie, na co dzień zajmujący się problematyką szeroko ujmowanej kultury, m.in. jej związków z innymi obszarami życia jednostkowego oraz wspólnotowego, różnic kulturowych, wzorów relacji danej kultury z kulturami obcymi, interpretacji fenomenów społecznych, politycznych, religijnych, z perspektywy kultury bądź kultur, dostrzegali w literaturze kulturoznawczej coraz bardziej doskwierający deficyt. Spowodowany był on - i jest nadal - relatywnie niewielką uwagą kierowaną na ważny obszar ludzkiej aktywności - kontakty interpersonalne oraz intergrupowe, przekraczające granice kultur, do których przynależą komunikujące się strony. Usunięcie tego braku nie nastąpi od razu. Z pewnością upłynie kilka lat, nim powstaną pierwsze polskie podręczniki, opracowania, monografie czy prace zbiorowe poświęcone tytułowemu fenomenowi. Próbą zmniejszenia tej luki jest powołanie czasopisma naukowego pod znamiennym tytułem: „Relacje Międzykulturowe”, o którym wspomnimy jeszcze w dalszej części tekstu.

Pogłębiony namysł oraz szczegółowe badania nad relacjami międzykulturowymi wynikają ponadto z konieczności zrozumienia mechanizmów, jakim podlegają podczas aktów komunikacyjnych jednostki i grupy

${ }^{1}$ Także w skali międzynarodowej relacje międzykulturowe jako przedmiot studiów należą do stosunkowo nowej problematyki w ramach studiów nad kulturą (cultural studies). 
o odmiennych doświadczeniach, stanowiących bagaż kulturowy o dużej sile oddziaływania. W dobie narastających ruchów migracyjnych o zróżnicowanych w globalnej skali przyczynach obserwujemy w Europie pierwszej dekady XXI wieku dominujący nurt migracji uchodźczej. Nasz kontynent stał się destynacją, schronieniem, symbolem bezpieczeństwa dla osób pochodzących z obszarów nękanych zbrojnymi konfliktami o podłożu polityczno-ekonomicznym i/lub etniczno-religijnym².

Przykłady relacji międzykulturowych w wymiarze międzynarodowym, zachodzących między reprezentantami różnych narodów, języków czy tradycji, zauważamy najprędzej. Jednak także w wymiarze krajowym wyczulone oko badacza, ale też spostrzegawczego amatora, dostrzeże odmienności kulturowe cechujące różne grupy, klasy czy warstwy społeczne tworzące polskie społeczeństwo. Ludzie młodzi mają kulturę nietożsamą z kulturą tworzoną i praktykowaną przez osoby starsze, podobnie jak mieszkańcy małych miejscowości przez doświadczenie i praktykę społeczną wypracowują wzory kultury specyficzne tylko dla nich, odmienne od obserwowanych w dużych miastach. Innym rytmem żyje Warszawa, innym Kraków, Wrocław czy Białystok, innym zaś Stróża, Lutowiska, Mielenko czy Udanin.

Różnice kulturowe wynikać mogą także z uwarunkowań gospodarczych, sprzyjających bądź niesprzyjających awansowi społeczno-ekonomicznemu członków społeczeństwa. W regionach o niskim potencjale przedsiębiorczym, ze słabym kapitałem ludzkim i/lub finansowym, funkcjonuje odmienny wzór kulturowy niż tam, gdzie potencjał ten jest silny, a kapitał - dobrze zarządzany. Będąca pochodną tych uwarunkowań jakość życia mieszkańców wpływa na wspólnotowe i jednostkowe wzory zachowań dotyczące między innymi szeroko rozumianej konsumpcji, skłonności do inwestowania lub jej braku, form spędzania wolnego czasu, poziomu i jakości wykształcenia, stopnia partycypacji w życiu politycznym, sposobu mieszkania etc. Innymi słowy, stopa życiowa jednostek i grup wpływa na ich kulturę. Należy jednak podkreślić, że oddziaływanie to jest zwrotne - kultura promuje pewne wzory zachowań, które wydają się najbardziej adekwatne do okoliczności, efektywne i pożądane przez zbiorowość czy wspólnotę.

Mnogość obszarów i płaszczyzn badawczo-analitycznych relacji międzykulturowych dostarcza zatem naukowcom zajmującym się studiami nad

\footnotetext{
2 Przykładem tego jest obszar Bliskiego Wschodu oraz Afryki Północnej, kolebka tak zwanej Arabskiej Wiosny, a raczej należałoby użyć określenia „arabskiej rewolucji”, która po 2010 roku objęła kraje takie, jak Irak, Libia, Syria, Egipt, Maroko, Algieria czy Tunezja.
} 
szeroko rozumianą kulturą bogatego materiału, pomocnego dla zrozumienia istoty jednostkowego i wspólnotowego bytu.

Czasopismo „Relacje Międzykulturowe” zostało pomyślane jako forum wypowiedzi dla polskich i zagranicznych kulturoznawców, stąd jego dwujęzyczna formuła. Zgodnie z nią naprzemiennie ukazywać się będą numery złożone raz z tekstów polskojęzycznych, raz z tekstów w języku angielskim, co pozwoli na poszerzenie grona czytelników także o środowisko zagraniczne. Wydaje się to o tyle ważne, że ze względu na barierę językową polska myśl naukowa rzadko jest obecna na scenie międzynarodowej, ze szkodą dla obu stron, bo jest z pewnością atrakcyjna przez swoją - kulturową właśnie - specyfikę, zresztą podobnie jak inne perspektywy i szkoły badawcze wywodzące się z krajów niedominujących ekonomicznie czy politycznie na arenie europejskiej i/lub globalnej ${ }^{3}$. Argument o ścisłym związku kondycji nauki i jej finansowego wsparcia jest przekonujący. Podobnie zresztą argument o odwrotnej korelacji, gdzie silna nauka przyciąga finanse. Tym bardziej więc powinniśmy się starać o umiejscowienie polskiej myśli kulturoznawczej bliżej centrum, nie zaś na peryferiach cywilizacji wyrosłej na podwalinach europejskiego dziedzictwa.

Monika Banaś, Franciszek Czech

${ }^{3}$ Warto w tym miejscu podać choć jeden z licznych przykładów spóźnionego odkrywania dokonań naukowców nienależących do anglojęzycznego środowiska: Jean Piaget, szwajcarski psycholog, którego przełomowe prace powstałe w latach 30. XX wieku zostały przybliżone międzynarodowemu czytelnikowi dopiero 30 lat później, kiedy przetłumaczono je na język angielski. 